\title{
Analisis Kreatifitas Kelompok Masyarakat Menghadapi Kondisi Ekonomi Rumah Tangga
}

\author{
Novita \\ Sekolah Tinggi Ilmu Ekonomi Riau (STIE RIAU) \\ Jln. HR. Subrantas 57 Panam Pekanbaru 28293 Telp. (0761) 63237 \\ E-mail : akbar_stier@yahoo.com
}

\begin{abstract}
: word creativity often we understand as an alternative and new innovations in human do when experiencing problems in dealing with problems. Creativity is also referred to as alternative work simplification so that it can produce a better product. Many definitions of creativity being addressed in accordance with permasalahnyaan. Housewife became one of the victims in the face of economic conditions, operationally housewife is a manager who manages the household finances and the need to provide creative art in optimizing the household expenses. De Jong \& Den Hartog (2003) also describes the stages of creative behaviors innovative in making the innovation process into four phases as follows: see opportunity, issuing idea, fight for and application results showed quite good, especially in terms of the opportunities and put out the idea, but still low in the fight for the chance to become applicable in the field.
\end{abstract}

Keywords: Creativity, Housewife

Kondisi perekonomian yang belum stabil seperti sekarang ini membuat ibu rumah tangga menanggung beban dalam pengeluaran rumah tangganya. Beban dalam rumah tangga khususnya rumah tangga miskin menjadi pekerjaan rumah yang berat dan perlu mendapatkan solusinya. Menurut Badan Pusat Statistik (BPS, 2015) mendefiniskan kemiskinan dengan menggunakan pendekatan konsumsi (satu dimensi). Dengan pendekatan ini, ditentukan ukuran konsumsi standar kehidupan yang "layak" dengan melihat kebutuhan dasar (basic need approach) yang menghasilkan Garis Kemiskinan (makanan dan bukan makanan). Garis Kemiskinan merupakan gabungan dari Garis Kemiskinan Makanan (GKM) dan Garis Kemiskinan non Makanan (GKBM).

GKM adalah nilai rupiah pengeluaran untuk kebutuhan minimum makanan yang disetarakan dengan 2100 kalori per kapita per hari. Paket komoditi kebutuhan dasar makanan ini diwakili oleh 52 jenis komoditi (padi-padian, umbi-umbian, ikan, daging, telur dan susu, sayuran, kacang-kacangan, buah-buahan, minyak lemak, dll Sedangkan GKBM adalah nilai rupiah pengeluaran untuk memenuhi kebutuhan dasar minimum non makanan yaitu papan, sandang, sekolah, trasportasi serta kebutuhan individu dan rumah tangga dasar lainnya. Paket komoditi kebutuhan dasar non makanan diwakili oleh 51 jenis komoditi (kelompok pengeluaran) di perkotaan dan 47 jenis komoditi (kelompok pengeluaran di pedesaan).

Garis Kemiskinan menunjukkan jumlah rupiah minimum yang dibutuhkan untuk memenuhi kebutuhan pokok minimum makanan yang setara dengan 2100 kilokalori perkapita per hari dan kebutuhan pokok non makanan. Penduduk yang memiliki rata-rata pengeluaran konsumsi per kapita per bulan di bawah Garis Kemiskinan, dikategorikan sebagai penduduk miskin. Dengan pendekatan konsumsi ini, maka BPS mendefinisikan kemiskinan sebagai suatu situasi dimana suatu standar kehidupan yang "layak" tidak tercapai. Dalam menentukan penduduk yang memiliki rata-rata pengeluaran per kapita per bulan di bawah garis kemiskinan dikategorikan penduduk miskin. Cara penentuan penduduk miskin semacam ini disebut penentuan kemiskinan absolut. 
Berdasarkan studi tersebut diperoleh delapan variabel yang layak dan operasional untuk diterapkan di lapangan (BPS, 2000), yaitu: luas lantai perkapita (lebih kecil atau lebih besar dari $8 \mathrm{~m}^{2}$ ), jenis lantai (tanah atau bukan tanah), ketersediaan air bersih (tidak terlindung atau terlindung), keberadaan jamban tidak ada atau ada, kepemilikan asset (tidak punya atau punya), variasi konsumsi lauk pauk (tidak bervariasi dan bervariasi), pembelian pakaian (minimal membeli satu stel pakaian atau tidak), kehadiran dalam kegiatan sosial (ya atau tidak). Kedelapan variabel tersebut telah mencakup aspek sosial dan ekonomi penduduk/rumahtangga diantaranya aspek sandang, pangan, perumahan, kepemilikan asset dan aktivitas sosial.

Pada tahun 2002, kedelapan variabelvariabel tersebut telah ditambahkan pada Susenas Kor, dimana variabel-variabel yang mengacu pada sifat-sifat yang mencirikan kemiskinan dan yang mengacu kepada sifat sifat yang mencirikan ketidak miskinan dimana skor 1 dan skor 0. Dengan demikian akan diperoleh skor maksimum 8 untuk yang paling miskin dan skor minimum yaitu 0 untuk yang paling tidak miskin. Berdasarkan hasil studi tahun 2000 ditetapkan bahwa skor batas untuk rumah tangga miskin adalah 5, artinya rumah tangga yang mempunyai skor 5 atau lebih akan dikategorikan miskin.

Dengan demikian akan diperoleh skor maksimum 8 untuk yang paling miskin dan skor minimum yaitu 0 untuk yang paling tidak miskin. Berdasarkan hasil studi tahun 2000 ditetapkan bahwa skor batas untuk rumah tangga miskin adalah 5 , artinya rumah tangga yang dengan skor 5 akan dikategorikan miskin.

Perbandingan

Rumahtangga

Penduduk Miskin hasil Pendekatan Delapan Karakteristik Rumahtangga Miskin dan Pendekatan Konsumsi pada tahun 2002 mengindikasikan bahwa pengukuran kemiskinan berdasarkan karakteristik rumahtangga miskin seharusnya tidak dilakukan secara seragam dan sentralistik, tetapi harus spesifik lokal dan dirancang oleh daerah dengan memperhatikan dinamika sosial setempat. Hal tersebut didasarkan pada kenyataan bahwa dalam periode sepuluh tahun terakhir, Indonesia pada satu sisi mengalami pertumbuhan ekonomi yang signifikan yang didukung oleh peningkatan pembangunan infrastruktur dan perkembangan teknologi yang pesat. Penurunan tingkat kemiskinan di Indonesia mengalami perlambatan, hal ini mengindikasikan bahwa masih banyak penduduk indonesia yang berada pada kondisi chronic poverty (kemiskinan kronis).

Hulme dan Shepherd (2003) mendefinisikan chronic poverty (kemiskinan kronis) sebagai suatu kondisi dimana seorang individu berada pada kondisi yang tidak pernah keluar dari kemiskinan selama lima tahun berturut turut. Selian itu, tingkat kemiskinan antarprovinsi juga mengalami ketimpangan, baik dari sisi jumlah penduduk miskin maupun persentase penduduk miskin di tingkat provinsi dan kabupaten/kota. Tingkat kemiskinan yang hanya didasarkan pada perhitungan moneter juga sudah mendaptkan berbagai pertanyaan dari berbagai pihak, termasuk pemerintah daerah.

Untuk memecahkan masalah ketimpangan pengeluaran di antara penduduk miskin digunakan ukuran Poverty Severity Index (P2). Indeks ini secara sederhana merupakan jumlah dari poverty gap tertimbang di mana penimbangnya sebanding dengan poverty gap itu sendiri. Dalam penghitungannya, indeks ini dapat diperoleh melalui rumus FGT dengan nilai $a=2$. Dengan mengkuadratkan poverty gap, indeks ini secara implisit memberikan penimbang yang lebih pada unit observasi yang makin jatuh di bawah garis kemiskinan. Semakin tinggi nilai indeks berarti semakin tinggi ketimpangan pengeluaran di antara penduduk miskin.

Sementara itu tidak tercapainya standar hidup yang layak oleh seseorang dipengaruhi oleh faktor-faktor yang sifatnya multidimensi seperti tidak mencukupinya 
kualitas SDM, kurangnya kesempatan produktif dan tidak mencukupinya perlindungan sosial. Rendahnya kualitas SDM dipengaruhi oleh akses terhadap pendidikan, kesehatan dan pelayanan lainnya yang diselenggarakan pemerintah. Sementara kurangnya kesempatan produktif dipengaruhi oleh rendahnya kemampuan dan iklim wirausaha khususnya bagi UMKM (Usaha Mikro Kecil dan Menengah). Sementara perlindungan sosial yang cukup akan melindungi masyarakat dari guncangan sosial yang dapat menyebabkan seseorang jatuh kedalam kemiskinan ketika terjadi bencana, sakit ataupun krisis ekonomi.

Perpres No 15 Tahun 2010 tentang Percepatan Penanggulangan Kemiskinan menyatakan bahwa program penanggulangan kemiskinan adalah kegiatan yang dilakukan oleh pemerintah, pemerintah daerah, dunia usaha, serta masyarakat untuk meningkatkan kesejahteraan masyarakat miskin melalui bantuan sosial, pemberdayaan masyarakat, pemberdayaan usaha ekonomi mikro dan kecil, serta program lain dalam rangka meningkatkan kegiatan ekonomi. Dengan demikian percepatan penanggulangan kemiskinan secara nasional dilakukan dengan strategi : 1. Mengurangi beban pengeluaran masyarakat miskin; 2. Meningkatkan kemampuan dan pendapatan masyarakat miskin; 3. Mengembangkan dan menjamin keberlanjutan Usaha Mikro dan Kecil; 4. Mensinergikan kebijakan dan program penanggulangan kemiskinan.

Berdasarkan uraian tersebut di atas, mempertanyakan masalah upaya menanggulagi beban hidup keluarga, maka salah satunya adan mengurangi beban pengeluaran masyarakat miskin. Beban ini dapat dicapai secara manajerial yakni melalui menumbuhkan kreatifitas ibu rumah tangga dalam melihat peluang pengurangan beban dan hingga mengaplikasikan dalam kondisi nyata.

Kata kreativitas seringkali kita pahami sebagai alternatif dan inovasi baru yang di lakukan manusia ketika mengalami kendala dalam menghadapi permasalahan. Kreativitas juga disebut sebagai alternatif penyederhanaan kerja sehingga dapat menghasilkan produk yang lebih baik. Banyak defenisi kreativitas yang di kemukakan sesuai dengan permasalahnyaan. James $\mathrm{R}$ Evan dalam Sutrisno (2010:110) menyatakan kreativitas adalah ketrampilan untuk menentukan pertalian baru, melihat subjek dari perspektif baru dan membentuk kombinasikombinasi baru dari dua atau lebih konsep yang telah tercetak dalam pikiran. Menurut Jensen Sinamo (2009: 178) kreativitas adalah estetika dan seni berkaitan dengan sukacita yang selanjutnya memicu pikiranpikiran cerdas dan kreatif. Kreatifitas menghasilkan karya-karya artistik-estetik serta pada saat yang sama mengembirakan hati. Sudah tentu pula, kegembiraan, sukacita dan kebahagiaan akan terwujud menjadi energy estetika yang mendesak untuk diekspresikan secara artistik.

Kreativitas adalah kemampuan individu dalam memunculkan suatu gagasan baru mencapai sesuatu terutama dari apa yang sudah diketahui, Ernie dan Kurniawan (2010). Kreativitas adalah seseorang yang hampir secara rutin menghasilkan hasil kreatif (Perkins, 1988). Menurut Suryana (2003) menyatakan bahwa kreativitas adalah: Berpikir sesuatu yang baru. Kreativitas sangat diperlukan dalam organisasi sebagai bagian dari kemampuan organisasi untuk terus beradaptasi dengan perubahan, Ernie dan Kurniawan (2010).

Kreativitas merupakan pemikiran unik/berbeda dengan kebiasaan tetapi mempuyai efek positif terhadap pencapai tujuann. Menurut Williams (2004) pemikiran divergen adalah proses yang menghasilkan banyak ide yang inovatif dan sekaligus menjadi aspek penting dari kreativitas anggota dalam organisasi. Faktor yang menyebabkan individu keratif adalah: 1) Pengalaman individu. 2) Perlakuan terhadap individu. 3) Kemampuan kognitif individu. (Ernie dan Kurniawan, 2010).

Kreativitas tidak muncul secara spontan akan tetapi mempunyai proses dalam diri indivdu. Seseorang dapat kreatif 
karena telah memiliki dasar pengetahuan sehingga memiliki keberanian diri untuk melakukan hal baru walaupun berhadapan dengan resiko. Menurut Ernie dan Kurniawan (2010) kreativitas di bangun oleh beberapa tahapan yaitu:

1) Preparation: tahap persiapan dapat berupa proses pendidikan atau pelatihan yang diberikan kepada individu.

2) Incubation: individu dikondisikan pada kondisi tertentu yang memungkinkan dirinya untuk mendapatkan gagasan baru mengenai sesuatu.

3) Insight: individu berhasil menemukan gagasan yang mungkin akan memberikan manfaat perubahan bagi organisasi,

4) Verivication: tahapan untuk merealisasikan gagasan.

De Jong \& Den Hartog (2003) juga menjelaskan tahap perilaku inovatif dalam melakukan proses inovasi menjadi 4 tahap sebagai berikut:

1) Melihat Peluang

Melihat peluang bagi karyawan untuk mengidentifikasi berbagai peluang/ kesempatan yang ada. Peluang dapat berawal dari ketidak kongruenan dan diskontinuitas yang terjadi karena adanya ketidaksesuaian dengan pola yang diharapkan misalnya timbulnya masalah pada pola kerja yang sudah berlangsung, adanya kebutuhan konsumen yang belum terpenuhi, atau adanya indikasi trends yang sedang berubah.

2) Mengeluarkan Ide

Dalam fase ini, karyawan mengeluarkan konsep baru dengan tujuan untuk perbaikan. Hal ini meliputi mengeluarkan ide sesuatu yang baru atau memperbaharui pelayanan, pertemuan dengan klien dan teknologi pendukung. Kunci dalam mengeluarkan ide adalah mengombinasikan dan mereorganisasikan informasi dan konsep yang telah ada sebelumnya untuk memecahkan masalah dan atau meningkatkan kinerja.

3) Memperjuangkan

Maksudnya disini untuk mengembangkan dan mengimplementasikan ide, karyawan harus memiliki perilaku yang mengacu pada hasil. Perilaku Inovasi Konvergen meliputi usaha menjadi juara dan bekerja keras. Seorang yang berperilaku juara mengeluarkan seluruh usahanya pada ide kreatif. Usaha menjadi juara meliputi membujuk dan mempengaruhi karyawan dan juga menekan dan bernegosiasi. Untuk mengimplementasikan inovasi sering dibutuhkan koalisi, mendapatkan kekuatan dengan menjual ide kepada rekan yang berpotensi.

\section{4) Aplikasi}

Dalam fase ini meliputi perilaku karyawan yang ditujukan untuk membangun, menguji, dan memasarkan pelayanan baru. Hal ini berkaitan dengan membuat inovasi dalam bentuk proses kerja yang baru ataupun dalam proses rutin yang biasa dilakukan.

Ada beberapa syarat kreativitas muncul pada diri individu sebagaimana di jelaskan oleh Frinces (2004) menyatakan bahwa syarat-syarat orang yang kreatif yaitu: a) keterbukaan terhadap pengalaman (openness to experience). b) pengamatan melihat dengan cara yang biasa dilakukan (observanvce seeing things in unusual ways). c) keinginan (curiosity) d) Toleransi terhadap ambiguitas (tolerance of apporites) e) kemandirian dalam penilaian, pikiran dan tindakan (independence in judgemnet, thought and action) f) memerlukan dan menerima otonomi (needing and assuming autonomy) $\mathrm{g}$ ) kepercayaan terhadap diri sendiri (self reliance) $\mathrm{h}$ ) idak sedang tunduk pada pengawasan kelompok (not being subject to group standart and control).

Menurut Martins \& Martins (2002) menyatkan bahawa kreativitas dan inovasi memiliki pengaruh tersendiri mengubah nilai, pola pikir dan perilaku sebelumnya yang telah terpola selanjutnya akan mempengaruhi performansi organisasi dalam kesehariannya.

Hasil penelitian Eddy Poernomo (2006) kreativitas tidak berpengaruh secara signifikan terhadap kinerja manajer. De Jong \& Den Hartog (2003) Perilaku 
inovatif dapat didefinisikan sebagai semua tindakan individu yang diarahkan pada generasi, pengenalan dan penerapan baru yang bermanfaat pada setiap tingkat organisasi. Setiap perilaku kreatif anggota organisasi merupakan hal positif bagi pencapaian tujuan organisasi. Individu kurang memiliki kreativitas berdampak pada perilaku kerja dan kinerja individu itu sendiri. Jadi kreativitas invidu sangat di harapkan organsasi terhadap anggonya sehingga dapat mencapai tujuan.

Sedangkan dimensi kreativitas menurut Sutrisno (2010: 111) antara lain: 1) nilai-nilai intelektual dan artistik; 2) ketertarikan pada kompleksitas; 3) kepedulian pada pekerjaan dan pencapaian; 4) ketekunan; 5) pemikiran yang mandiri; 6) otonom; 7) kepercayaan diri; 8) kesiapan mengambil resiko.

Dimensi kreativitas yang digunakan dalam penelitian ini menurut Sutrisno (2010: 111) antara lain:

1. Nilai-nilai intelektual dan artistik; merupakan gambaran kemampuan intelektualitas dan seni dari seorang karyawan dalam menghasilkan produk yang baik.

2. Ketertarikan pada kompleksitas; Merupakan keinginan yg dirasakan untuk dapat diwujudkan oleh karyawan dalam bekerja.

3. Kepedulian pada pekerjaan dan pencapaian; merupakan bentuk nilai capaian akan keberhasilan bagi seorang karyawan.

4. Ketekunan; merupakan bentuk kerja keras dalam menghasilkan hasil kerja yang optimal.

5. Pemikiran yang mandiri; merupakan kemampuan dalam menghasilkan hal yang baru yang berguna untuk menyelesaikan pekerjaan seperti idea tau gagasan.

6. Otonom; merupakan wujud karyawan yang berdiri sendiri dalam menghasilkan produk bukan tergantung pada pihak lain

7. Peraya diri; merupakan sikap keyakinan yang mantap akan hasil kerja untuk diwujudkan.
8. Kesiapan mengambil resiko; merupakan bentuk usaha tampil beda dalam mencapai tujuan.

De Jong \& Den Hartog (2003) juga menjelaskan tahap perilaku inovatif dalam melakukan proses inovasi menjadi 4 tahap sebagai berikut:

1. Melihat Peluang. Melihat peluang bagi karyawan untuk mengidentifikasi berbagai peluang/kesempatan yang ada. Peluang dapat berawal dari ketidak kongruenan dan diskontinuitas yang terjadi karena adanya ketidaksesuaian dengan pola yang diharapkan misalnya timbulnya masalah pada pola kerja yang sudah berlangsung, adanya kebutuhan konsumen yang belum terpenuhi, atau adanya indikasi trends yang sedang berubah.

2. Mengeluarkan Ide. Dalam fase ini, karyawan mengeluarkan konsep baru dengan tujuan untuk perbaikan. Hal ini meliputi mengeluarkan ide sesuatu yang baru atau memperbaharui pelayanan, pertemuan dengan klien dan teknologi pendukung. Kunci dalam mengeluarkan ide adalah mengombinasikan dan mereorganisasikan informasi dan konsep yang telah ada sebelumnya untuk memecahkan masalah dan atau meningkatkan kinerja.

3. Memperjuangkan. Maksudnya disini untuk mengembangkan dan mengimplementasikan ide, karyawan harus memiliki perilaku yang mengacu pada hasil. Perilaku Inovasi Konvergen meliputi usaha menjadi juara dan bekerja keras. Seorang yang berperilaku juara mengeluarkan seluruh usahanya pada ide kreatif. Usaha menjadi juara meliputi membujuk dan mempengaruhi karyawan dan juga menekan dan bernegosiasi. Untuk mengimplementasikan inovasi sering dibutuhkan koalisi, mendapatkan kekuatan dengan menjual ide kepada rekan yang berpotensi. 
4. Aplikasi. Dalam fase ini meliputi perilaku karyawan yang ditujukan untuk membangun, menguji, dan memasarkan pelayanan baru. Hal ini berkaitan dengan membuat inovasi dalam bentuk proses kerja yang baru ataupun dalam proses rutin yang biasa dilakukan.

\section{METODE}

Pendekatan survey dilakukan dalam penelitian ini dengan menggunakan sampel kelompok masyarakat di perumahan di Kota Pekanbaru, mengambilan sampel sebanyak 30 orang secara acak. Pengumpulan data dengan menggunakan kuesioner dan data dianalisis dengan teknik deskriptif.

\section{HASIL}

Seiring dengan perkembangan daerah ini sebagai pusat perdagangan dan pemerintahan. Kemudian juga dikarenakan daerah ini berbatasan langsung dengan negara tetangga sehingga memberikan peluang besar dalam memasarkan produknya. Kota Pekanbaru memiliki luas 632,26 $\mathrm{Km}^{2}$ dengan jumlah penduduk tahun 2011 sebanyak 902.464 jiwa dan kota ini tergolong kota besar. Kepadatan penduduk mencapai 1.420 orang per kilometernya, daerah ini memiliki 12 Kecamatan dan memiliki visi sebagai: "pusat perdagangan dan bisnis kemudian sebagai pusat pendidikan dan sebagai pusat kebudayaan melayu".

Semenjak era otonomi daerah dengan diberlakukannya UU No. 32 tahun 2004 tentang pemerintahan daerah, ini memberikan angin segar bagi daerah untuk membangun dan mengembangkan perekonomiannya. Sehingga tumbuh dan berkembanglah kota-kota di daerah yang pada akhirnya mengundang para pencari kerja untuk pergi ke kota. Perkembangan penduduk terus mengalami peningkatan, peningkatan ini diperkirakan akan terus meningkat, berikut ini data perkembangan jumlah penduduk di kota Pekanbaru.

Data berikut ini menunjukkan kebutuhan ruang di kota Pekanbaru semakin tinggi karena perkembangan penduduk yang juga tinggi. Hal ini menyebabkan ruang yang tersedia semakin sempit. Pertambahan jumlah penduduk ini lebih didominasi penduduk yang datang. Kemajemukan masyarakat juga terdapat di Pekanbaru. Menurut sensus BPS Kota Pekanbaru yang dilakukan, persentase etnis yang ada di Pekanbaru terdiri dari Melayu $(26,1 \%)$, Jawa $(15,1 \%)$, Minang $(37,7 \%)$, Batak $(10,8 \%)$, Banjar $(0,2 \%)$, Bugis $(0,2 \%)$, Sunda $(1,0 \%)$, dan suku-suku lainnya $(8,8 \%)$.

Tabel 1: Perkembangan Penduduk di Kota Pekanbaru Tahun 2006-2010

\begin{tabular}{|c|c|c|c|c|c|c|}
\hline \multirow{2}{*}{$\begin{array}{l}\mathrm{N} \\
\mathrm{o}\end{array}$} & \multirow{2}{*}{ Uraian } & \multicolumn{5}{|c|}{ Tahun } \\
\hline & & 2006 & 2007 & 2008 & 2009 & 2010 \\
\hline 1. & Jumlah penduduk & $\begin{array}{l}754 . \\
467\end{array}$ & $\begin{array}{l}779 . \\
899\end{array}$ & $\begin{array}{l}799 . \\
213\end{array}$ & $\begin{array}{l}802 . \\
788\end{array}$ & $\begin{array}{l}897 . \\
768\end{array}$ \\
\hline 2. & Kepala keluarga & $\begin{array}{l}169 . \\
957\end{array}$ & $\begin{array}{l}175 . \\
859\end{array}$ & $\begin{array}{l}177 . \\
762\end{array}$ & $\begin{array}{l}188 . \\
341 \\
\end{array}$ & $\begin{array}{l}213 . \\
795\end{array}$ \\
\hline 3. & \begin{tabular}{cl}
\multicolumn{2}{l}{ Jenis kalamin } \\
- & Laki- \\
& laki \\
- & Peremp \\
& uan \\
\end{tabular} & $\begin{array}{l}380 . \\
993 \\
373 . \\
474\end{array}$ & $\begin{array}{l}389 . \\
972 \\
389 . \\
927\end{array}$ & $\begin{array}{l}400 . \\
505 \\
398 \\
708\end{array}$ & $\begin{array}{l}403 . \\
900 \\
398 . \\
888\end{array}$ & $\begin{array}{l}456 . \\
386 \\
441 \\
382\end{array}$ \\
\hline 4. & $\begin{array}{cl}\text { Mutasi penduduk } \\
- & \text { Kalahir } \\
& \text { an } \\
- & \text { Kemati } \\
& \text { an } \\
- & \text { Pindah } \\
- & \text { Datang }\end{array}$ & $\begin{array}{l}7.95 \\
3 \\
2.77 \\
7 \\
9.76 \\
4 \\
21.9 \\
16 \\
\end{array}$ & $\begin{array}{l}10.5 \\
09 \\
3.57 \\
2 \\
11.2 \\
31 \\
27.1 \\
31\end{array}$ & $\begin{array}{l}11.7 \\
82 \\
2.08 \\
0 \\
7.36 \\
2 \\
16.8 \\
13 \\
\end{array}$ & $\begin{array}{l}11.2 \\
55 \\
4.30 \\
7 \\
19.6 \\
37 \\
22.2 \\
11 \\
\end{array}$ & $\begin{array}{l}- \\
- \\
-\end{array}$ \\
\hline 5. & $\begin{array}{l}\text { Kepadatan } \\
\text { penduduk }\end{array}$ & $\begin{array}{l}1.19 \\
3\end{array}$ & $\begin{array}{l}1.23 \\
4 \\
(3.4 \\
\%) \\
\end{array}$ & $\begin{array}{l}1.26 \\
4 \\
(2.5 \\
\%) \\
\end{array}$ & $\begin{array}{l}1.27 \\
0 \\
(0.4 \\
\%) \\
\end{array}$ & $\begin{array}{l}1.42 \\
0 \\
(11.8 \\
\%) \\
\end{array}$ \\
\hline
\end{tabular}

Sumber: BPS Kota Pekanbaru (2011) dan Distardukcapil (2012)

Berdasarkan hasil survey di lapangan berkaitan dengan kreatifitas sebagai wujud inovasi dalam rangka mengurangi beban pengeluaran rumah tangga dapat dilihat pada uraian data berikut ini:

\section{a. Melihat peluang:}

Melihat peluang bagi karyawan untuk mengidentifikasi berbagai peluang/kesempatan yang ada. Peluang dapat berawal dari ketidak kongruenan dan diskontinuitas yang terjadi karena adanya ketidaksesuaian dengan pola yang diharapkan misalnya timbulnya masalah pada pola kerja yang sudah berlangsung, adanya kebutuhan konsumen yang belum terpenuhi, atau 
adanya indikasi trends yang sedang berubah.

Tabel 2: Kreatifitas dilihat dari melihat peluang masalah pengeluaran dalam rumah tangga

\begin{tabular}{|c|c|c|c|c|c|c|c|}
\hline $\begin{array}{l}\mathrm{N} \\
\mathrm{o}\end{array}$ & $\begin{array}{l}\text { Melihat peluang } \\
\text { masalah }\end{array}$ & $\begin{array}{l}\mathrm{S} \\
\mathrm{S}\end{array}$ & $S$ & $\mathrm{R}$ & $\begin{array}{l}K \\
S\end{array}$ & $\begin{array}{l}\mathrm{T} \\
\mathrm{S}\end{array}$ & $\begin{array}{l}\text { Sko } \\
\mathrm{r}\end{array}$ \\
\hline 1 & $\begin{array}{l}\text { Masalah kebutuhan } \\
\text { keluarga yang semakin } \\
\text { meningkat akibat dari } \\
\text { kondisi ekonomi sat } \\
\text { ini }\end{array}$ & 17 & 7 & 5 & 1 & & 4.33 \\
\hline 2 & $\begin{array}{l}\text { Penghasilan keluarga } \\
\text { yang cenderung } \\
\text { kurang stabil } \\
\text { sedangkan kebutuhan } \\
\text { terus meningkat dalam } \\
\text { keluarga }\end{array}$ & 3 & $\begin{array}{l}1 \\
2\end{array}$ & $\begin{array}{l}1 \\
0\end{array}$ & 5 & & 3.43 \\
\hline 3 & $\begin{array}{l}\text { Adanya pemikiran } \\
\text { untuk melakukan } \\
\text { efisiensi dalam } \\
\text { mengatur pengeluaran } \\
\text { rumah tangga }\end{array}$ & 20 & $\begin{array}{l}1 \\
0\end{array}$ & & & & 4.67 \\
\hline & Rata-rata & 13 & $\begin{array}{l}1 \\
0\end{array}$ & 5 & 2 & 0 & 4.14 \\
\hline
\end{tabular}

Sumber: Data Olahan, 2016

Dari tabel tersebut dijelaskan bahwa pada umumnya ibu rumah tangga sudah sanga jeli melihat masalah dan kebutuhan serta adanya perubahan dalam rumah tanggnya dengan skor nilai 4,14 yang berarti sangat setuju adanya masalah pengeluaran rumah tangga dengan kondisi ekonomi saat ini.

- Masalah (Masalah kebutuhan keluarga yang semakin meningkat akibat dari kondisi ekonomi sat ini) dinyatakan dalam skor 4,33 dalam arti bahwa Masalah kebutuhan keluarga yang semakin meningkat akibat dari kondisi ekonomi sat ini.

- Kebutuhan konsumen yang belum terpenuhi (Penghasilan keluarga yang cenderung kurang stabil sedangkan kebutuhan terus meningkat dalam keluarga) dengan skor 3,43 berarti penghasilan keluarga yang cenderung kurang stabil sedangkan kebutuhan terus meningkat dalam keluarga

- Adanya perubahan (adanya pemikiran untuk melakukan efisiensi dalam mengatur pengeluaran rumah tangga) dengan skor 4,67 yang berarti bahwa adanya pemikiran untuk melakukan efisiensi dalam mengatur pengeluaran rumah tangga.

\section{b. Mengeluarkan ide}

Dalam fase ini, karyawan mengeluarkan konsep baru dengan tujuan untuk perbaikan. Hal ini meliputi mengeluarkan ide sesuatu yang baru atau memperbaharui pelayanan, pertemuan dengan klien dan teknologi pendukung. Kunci dalam mengeluarkan ide adalah mengombinasikan dan mereorganisasikan informasi dan konsep yang telah ada sebelumnya untuk memecahkan masalah dan atau meningkatkan kinerja.

Tabel3: Kreatifitas dilihat dari mengelurkan ide pemecahan masalah pengeluaran dalam rumah tangga

\begin{tabular}{|c|c|c|c|c|c|c|c|}
\hline $\begin{array}{l}\mathrm{N} \\
\mathrm{o}\end{array}$ & $\begin{array}{l}\text { Mengeluarkan ide } \\
\text { pemecahan masalah }\end{array}$ & $\begin{array}{l}\mathrm{S} \\
\mathrm{S}\end{array}$ & $\mathrm{S}$ & $\mathrm{R}$ & $\begin{array}{l}\mathrm{K} \\
\mathrm{S}\end{array}$ & $\begin{array}{l}\mathrm{T} \\
\mathrm{S}\end{array}$ & $\begin{array}{l}\text { Sk } \\
\text { or }\end{array}$ \\
\hline 4 & $\begin{array}{l}\text { Saya terus memikirkan } \\
\text { bagaimana cara mengatasi } \\
\text { masalah meningkatnya } \\
\text { kebutuhan dalam } \\
\text { keluarga }\end{array}$ & 6 & $\begin{array}{l}1 \\
1\end{array}$ & 9 & 4 & & $\begin{array}{l}3.6 \\
3\end{array}$ \\
\hline 5 & $\begin{array}{l}\text { Beberapa solusi dapat } \\
\text { saya peroleh guna } \\
\text { mengatasi masalah } \\
\text { kebutuhan keluarga }\end{array}$ & 5 & 9 & $\begin{array}{l}1 \\
3\end{array}$ & 3 & & $\begin{array}{l}3.5 \\
3\end{array}$ \\
\hline 6 & $\begin{array}{l}\text { Saya selalu berencana } \\
\text { melakukan perubahan } \\
\text { dalam mengatasi masalah } \\
\text { kebutuhan dalam } \\
\text { keluarga }\end{array}$ & 8 & $\begin{array}{l}1 \\
2\end{array}$ & $\begin{array}{l}1 \\
0\end{array}$ & & & $\begin{array}{l}3.9 \\
3\end{array}$ \\
\hline & Rata-rata & 6 & $\begin{array}{l}1 \\
1\end{array}$ & $\begin{array}{l}1 \\
1\end{array}$ & 2 & 0 & $\begin{array}{l}3.7 \\
0\end{array}$ \\
\hline
\end{tabular}

Sumber: Data Olahan, 2016

Pada tabel tersebut dijelaskan bahwa kreatifitas ibu rumah tanga menghadapi masalah pengeluaran rumah tangga dilihat dari mengeluaran ide pemecahan masalah dengan skor 3,70 yang artinya ibu rumah tangga sudah cukup baik dalam memikirkan, mencari solusi dan jugga merencanakan perubahan dalam keluarga.

- Memikirkan (terus memikirkan bagaimana cara mengatasi masalah meningkatnya kebutuhan dalam keluarga) dengan skor 3,63 yang berarti bahwa terus memikirkan bagaimana cara mengatasi masalah meningkatnya kebutuhan dalam keluarga. 
- Mencari solusi (Beberapa solusi dapat diperoleh guna mengatasi masalah kebutuhan keluarga) dengan skor 3,53 yang berarti bahwa beberapa solusi dapat diperoleh guna mengatasi masalah kebutuhan keluarga

- Merencanakan (selalu berencana melakukan perubahan dalam mengatasi masalah kebutuhan dalam keluarga) dengan skor 3,93 yang berarti bahwa selalu berencana melakukan perubahan dalam mengatasi masalah kebutuhan dalam keluarga.

\section{c. Memperjuangkan}

Maksudnya disini untuk
mengembangkan mengimplementasikan ide, karyawan harus memiliki perilaku yang mengacu pada hasil. Perilaku Inovasi Konvergen meliputi usaha menjadi juara dan bekerja keras. Seorang yang berperilaku juara mengeluarkan seluruh usahanya pada ide kreatif. Usaha menjadi juara meliputi membujuk dan mempengaruhi karyawan dan juga menekan dan bernegosiasi. Untuk mengimplementasikan inovasi sering dibutuhkan koalisi, mendapatkan kekuatan dengan menjual ide kepada rekan yang berpotensi.

Tabel 4: Kreatifitas dilihat dari memperjuangkannya terealisasinya masalah pengeluaran

\begin{tabular}{|c|c|c|c|c|c|c|c|}
\hline $\begin{array}{l}\mathrm{N} \\
\mathrm{o}\end{array}$ & $\begin{array}{l}\text { Memperjuangkan terelisasinya } \\
\text { pemecahan masalah }\end{array}$ & $\begin{array}{l}S \\
S\end{array}$ & $\mathrm{~S}$ & $\mathrm{R}$ & $\begin{array}{l}\mathrm{K} \\
\mathrm{S}\end{array}$ & $\begin{array}{l}\mathrm{T} \\
\mathrm{S}\end{array}$ & $\begin{array}{l}\text { Sk } \\
\text { or }\end{array}$ \\
\hline 7 & $\begin{array}{l}\text { Saya melakukan apa yang } \\
\text { saya rencanakan sebisa } \\
\text { mungkin }\end{array}$ & & 3 & $\begin{array}{l}1 \\
2\end{array}$ & $\begin{array}{l}1 \\
0\end{array}$ & 5 & $\begin{array}{l}2 . \\
43\end{array}$ \\
\hline 8 & $\begin{array}{l}\text { Saya juga selalu berdiskusi } \\
\text { dengan sesama ibu rumah } \\
\text { tangga lain dalam masalah } \\
\text { yang sama }\end{array}$ & 2 & 8 & $\begin{array}{l}1 \\
5\end{array}$ & 5 & & $\begin{array}{l}3 . \\
23\end{array}$ \\
\hline 9 & $\begin{array}{l}\text { Saya berusaha untuk } \\
\text { mendapatkan dukungan dari } \\
\text { ibu-ibu rumah tangga lain } \\
\text { untuk mereka bisa terapkan } \\
\text { dirumah }\end{array}$ & & 1 & $\begin{array}{l}1 \\
4\end{array}$ & $\begin{array}{l}1 \\
0\end{array}$ & 5 & $\begin{array}{l}2 . \\
37\end{array}$ \\
\hline & Rata-rata & 1 & 4 & $\begin{array}{l}1 \\
4\end{array}$ & 8 & 3 & $\begin{array}{l}2 . \\
68\end{array}$ \\
\hline
\end{tabular}

Sumber: Data Olahan, 2016
Tabel di atas dapat dijelaskan bahwa kreatifitas ibu rumah tangga dalam menghadapi pengeluarannya dilihat dari memperjuangkan tereliasasinya pemecahan masalah dengan skor 2,68 yang berarti dalam hal kerja keras, membujuk dan mempengaruhi masih rendah.

- Kerja keras (Saya melakukan apa yang saya rencanakan sebisa mungkin) dengan skor 2,43 yang berarti masih kurang dalam memperjuangkan terelisasinya pemecahan masalah

- Membujuk (Saya juga selalu berdiskusi dengan sesama ibu rumah tangga lain dalam masalah yang sama) dengan skor 3,23 yang berarti jarang berdiskusi dengan sesama ibu rumah tangga lain dalam masalah yang sama

- Mempengaruhi (Saya berusaha untuk mendapatkan dukungan dari ibu-ibu rumah tangga lain untuk mereka bisa terapkan dirumah) dengan skor 2,37 yang berarti kurang berusaha untuk mendapatkan dukungan dari ibu-ibu rumah tangga lain untuk mereka bisa terapkan di rumah.

\section{d. Aplikasi}

Dalam fase ini meliputi perilaku karyawan yang ditujukan untuk membangun, menguji, dan memasarkan pelayanan baru. Hal ini berkaitan dengan membuat inovasi dalam bentuk proses kerja yang baru ataupun dalam proses rutin yang biasa dilakukan. 
Tabel 5: Kreatifitas dilihat dari penerapan pemecahan masalah pengeluaran dalam rumah tangga

\begin{tabular}{|c|c|c|c|c|c|c|c|}
\hline $\begin{array}{l}\mathrm{N} \\
\mathrm{o}\end{array}$ & $\begin{array}{l}\text { Penerapan pemecahan } \\
\text { masalah }\end{array}$ & $\begin{array}{l}S \\
S\end{array}$ & $\mathrm{~S}$ & $\mathrm{R}$ & $\begin{array}{l}\mathrm{K} \\
\mathrm{S}\end{array}$ & $\begin{array}{l}\mathrm{T} \\
\mathrm{S}\end{array}$ & $\begin{array}{l}\text { Sko } \\
\text { r }\end{array}$ \\
\hline 10 & $\begin{array}{l}\text { Saya berhasil } \\
\text { menerapkan cara } \\
\text { mengatasi masalah } \\
\text { kebutuhan rumah tangga } \\
\text { di lingkungan tempat } \\
\text { tinggal saya }\end{array}$ & & & $\begin{array}{l}1 \\
0\end{array}$ & 17 & 3 & $\begin{array}{l}2.2 \\
3\end{array}$ \\
\hline 11 & $\begin{array}{l}\text { Saya selalu mencari } \\
\text { kelemahan dalam } \\
\text { penerapannya }\end{array}$ & & & $\begin{array}{l}1 \\
3\end{array}$ & 14 & 3 & $\begin{array}{l}2.3 \\
3\end{array}$ \\
\hline 12 & $\begin{array}{l}\text { Saya merasa senang } \\
\text { dapat berbuat dalam } \\
\text { keluarga dalam } \\
\text { mengatasi masalah } \\
\text { kebutuhan keluarga }\end{array}$ & & & 1 & 20 & 9 & $\begin{array}{l}1.7 \\
3\end{array}$ \\
\hline & Rata-rata & 0 & 0 & 8 & 17 & 5 & $\begin{array}{l}2.1 \\
0\end{array}$ \\
\hline
\end{tabular}

Sumber: Data Olahan, 2016

Tabel di atas dapat dijelaskan bahwa kreatifitas ibu rumah tangga dalam menghadapi pengeluarannya dilihat dari penerapan pemecahan masalah dengan skor 2,10 yang berarti dalam hal membangun, menguji dan menerapkan masih rendah.

- Membangun (Saya berhasil menerapkan cara mengatasi masalah kebutuhan rumah tangga di lingkungan tempat tinggal saya) dengan skor 2,23 yang berarti tidak berhasil menerapkan cara mengatasi masalah kebutuhan rumah tangga di lingkungan tempat tinggal

- Menguji (saya selalu mencari kelemahan dalam penerapannya) dengan skor 2,33 yang berarti tidak pernah mencari kelemahan dalam penerapannya

- Menerapkan (saya merasa senang dapat berbuat dalam keluarga dalam mengatasi masalah kebutuhan keluarga) dengan skor 1,73 yang berarti merasa tidak senang dapat berbuat dalam keluarga dalam mengatasi masalah kebutuhan keluarga.

Dari beberapa indikator kreatifitas tersebut di atas, maka dapat dibuat rekapitulasi data sebagai berikut:
Tabel 5.6: Kreatifitas dilihat dari seluruh indikator masalah pengeluaran dalam rumah tangga

\begin{tabular}{|c|c|c|c|c|c|c|c|}
\hline $\begin{array}{l}\mathrm{N} \\
\mathrm{o}\end{array}$ & Indikator & $\begin{array}{l}\mathrm{S} \\
\mathrm{S}\end{array}$ & $\mathrm{S}$ & $\mathrm{R}$ & $\begin{array}{l}\mathrm{K} \\
\mathrm{S}\end{array}$ & $\begin{array}{l}\mathrm{T} \\
\mathrm{S}\end{array}$ & $\begin{array}{l}\text { Sk } \\
\text { or }\end{array}$ \\
\hline 1 & Melihat peluang masalah & $\begin{array}{l}1 \\
3\end{array}$ & $\begin{array}{l}1 \\
0\end{array}$ & 5 & 2 & 0 & $\begin{array}{l}4 . \\
14\end{array}$ \\
\hline 2 & $\begin{array}{l}\text { Mengeluarkan ide } \\
\text { pemecahan masalah }\end{array}$ & 6 & $\begin{array}{l}1 \\
1\end{array}$ & $\begin{array}{l}1 \\
1\end{array}$ & 2 & 0 & $\begin{array}{l}3 . \\
70\end{array}$ \\
\hline 3 & $\begin{array}{l}\text { Memperjuangkan } \\
\text { terelisasinya pemecahan } \\
\text { masalah }\end{array}$ & 1 & 4 & $\begin{array}{l}1 \\
4\end{array}$ & 8 & 3 & $\begin{array}{l}2 . \\
68\end{array}$ \\
\hline 4 & $\begin{array}{l}\text { Penerapan pemecahan } \\
\text { masalah }\end{array}$ & 0 & 0 & 8 & $\begin{array}{l}1 \\
7\end{array}$ & 5 & $\begin{array}{l}2 . \\
10\end{array}$ \\
\hline & Rata-rata & 5 & 6 & 9 & 7 & 2 & $\begin{array}{l}3 . \\
16\end{array}$ \\
\hline
\end{tabular}

Sumber: Data Olahan, 2016

Dari data tersebut dapat dijelaskan bahwa kreatifitas ibu rumah tangga dalam menghadapi pengeluaran yang meningkat dengan skor rata-rata sebesar 3.16 yang berarti dalam kategori cukup. Dari empat indikator, diketahui bahwa dua indiaktor dalam kondisi baik yakni melihat peluang masalah yang dihadapi oleh masyarakat dan juga mengeluarkan ide dalam rangka memecahkan masalah. Sedangkan dua indikator lainnya dalam kondisi rendah yakni memperjuangkan ide untuk dapat direalisasikan dan penerapannya dalam bentuk aplikasi.

\section{PEMBAHASAN}

Kondisi kreatifitas ibu rumah tangga yang masih cukup ini disebabkan oleh beberapa hal, antara lain:

a. Latar belakang pendidikan

Pendidikan memberikan andil yang cukup besar dalam rangka mengatasi berbagai masalah, masalah dalam rumah tangga selalu menjadi prioritas utama yang perlu mendapatkan solusinya dan selama ini ibu rumah tangga masih kurang mendapatkan pengetahuan mengenai bagaimana cara mengatasi dan mengelola serta mengatur kondisi keuangan keluarga.

b. Kemampuan ekonomi

Ekonomi keluarga menjadi masalah tersendiri dalam rangka 
menumbuhkan kreatifitas, karena dengan adanya kondisi ekonomi keluarga yang cenderung kurang membaik menyebabkan keterpaksaan dalam rumah tangga, mereka memiliki ide namun tidak mampu merealisasikannya.

c. Pengalaman

Belum adanya pengalaman membuat ibu rumah tangga kurang berhasil dalam menyelesaikan masalah pengeluaran rumah tangga, seyogyanya melalui pelatihan dan pencerahan yang diberikan dan praktek langsung menjadi sesuatu yang dapat membantu menyelesaikan masalah yang dihadapi.

\section{SIMPULAN}

Berdasarkan hasil penelitian maka dapat ditarik kesimpulan berkaitan dengan kreatifitas ibu rumah tangga sebagai berikut:

a. Hasil penelitiannya menunjukkan kreatifitas cukup baik terutama dalam hal melihat peluang dan mengeluarkan ide, namun masih rendah dalam memperjuangkan peluang menjadi aplikatif di lapangan.

b. Faktor pendidikan, kondisi ekonomi dan pengalaman menjadi faktor penentu tingkat kreatifitas ibu rumah tangga dalam menghadapi kondisi pengeluaran rumah tangga.

\section{DAFTAR RUJUKAN}

De Jong, J \& Hartog, D D. (2003). Leadership as a determinant of innovative behaviour. A Conceptual framework. http://www.entrepreneurshipsme.eu/pdf-ez/H200303.pdf. Harus di buka di Internet.
Eddy Poernomo (2006) Pengaruh Kreativitas dan Kerjasama Tim Terhadap Kinerja Manajer pada PT. Jesslyn K Cakes Indonesia Cabang Surabaya. Adm.Bisnis UPN Veteran Jawa Timur. Jurnal Ilmu-Ilmu Ekonomi Vol.6 No.2 September 2006 : 102-108.

Edy Sutrisno, "Budaya Organisasi," Kencana Prenada Media Group, 2010.

Frinces, Heflin, 2004. Kewirausahaan dan Inovasi Bisnis. Cetakan Pertama, Penerbit: Darusalam, Yogyakarta.

Jensen Sinamo,"Etos Kerja Dalam Bisnis, " Institute Dharma Mahardika, 2009.

Arthur Keown J, David Scott F, Jhon Martin D, William Petty J, 2002, Dasar -. Dasar Manajemen Keuangan, Penerbit Salemba Empat 